\title{
ДИФФЕРЕНЦИАЦИЯ СЕЛЬСКОХОЗЯЙСТВЕННЫХ УГОДИЙ ПО ПЛОЩАДЯМ НА ПРИМЕРЕ ТОМСКОГО РАЙОНА
}

\author{
Пасько Ольга Анатольевна', \\ oap@tpu.ru
}

\author{
Захарченко Александр Викторович², \\ zakh.al.vic@yandex.ru \\ Поспелова Екатерина Викторовна', \\ kate_fro@@mail.ru
' Национальный исследовательский Томский политехнический университет, Россия, 634050, г. Томск, пр. Ленина, 30.
2 Институт проблем освоения Севера Федерального государственного бюджетного учреждения науки Тюменского научного центра Сибирского отделения Российской академии наук, 625026, г. Тюмень, ул. Малыгина, 86.

\begin{abstract}
Актуальность исследования обусловлена необходимостью оптимизации размеров земельных участков для совершенствования организации использования земель сельскохозяйственного назначения в зоне рискованного земледелия. Цель: анализ сложившегося пространственного распределения площадей хозяйств и земельных участков сельскохозяйственного назначения для выбора путей оптимизации их использования.

Объекты: 3309 земельных участков 25 хозяйств, расположенных в Томском районе на юго-востоке Томской области. Методы: аналитический, картографический, корреляционный, регрессионный и кластерный виды анализа.

Результаты. Проведен анализ выборки, имеющей 3309 значений площадей земельных участков из 25 хозяйств Томского района, и определены ее основные статистические показатели. Полимодальность выборки и ее несоответствие нормальному распределению определили непараметрические методы анализа. На основе иерархического кластерного анализа предложена таксономия (общие размеры участка, масштаб, стандартизация по близости к региональному стандарту, относительные отклонения от стандарта, относительные размеры и принадлежность к хозяйству) и классификация площадей земельных участков сельскохозяйственного назначения. Установлено, что площади, непригодные и малопригодные (закустаренные) для ведения сельского хозяйства, составляют 44 \% от общего количества. Кормовыми культурами занята почти половина земель, садовыми и овощными 7 и 2 \% соответственно. Доминируют серые лесные почвы (45 \% участков), 14 \% участков покрывают светло-серые лесные почвы, а 11 \% - все остальные типы. Дерновые глубоко-подзолистые, дерново-глеевые и дерново-глееватые почвы на землях сельскохозяйственного назначения встречаются редко. Положение земельных участков в ландшафте в основном элювиальное (72 \% участков) и трансэлювиальное (21 \% участков). Менее сотни участков характеризуются супераквальными почвами. Показано, что в Томском районе такие факторы, как тип почв, бонитет почв, положение в ландшафте и хозяйственное назначение не оказывают влияние на размеры площади сельскохозяйственного участка. Установлена линейная зависимость между средней площадью земельного участка и числом участков в хозяйстве, что указывает на их стандартизацию внутри хозяйства. Проведена классификация земельных участков по их площадным размерам и принадлежности к регламенту.
\end{abstract}

\section{Ключевые слова:}

Земельный участок, сельскохозяйственное назначение, площадь, тип почв, балл бонитета, положение в ландшафте, кластерный анализ, корреляционный анализ, классификация, недостатки землепользования.

\section{Введение}

Эффективность агропромышленного комплекса во многом определяется соответствием его потенциала особенностям природных условий [1] и применяемым технологиям [2]. Игнорирование этого положения привело в России к недоиспользованию геополитического преимущества и обострению «земельного вопроса» [3]. Необходима программа, содержащая инновационные подходы, и финансовые возможности для ее реализации и реагирования на экономические, социальные, экологические, климатические и технологические вызовы [4]. Приоритетами становятся минимизация живого и овеществленного труда, снижение ущерба природнотерриториальному комплексу и достижение максимума производства высококачественной продукции [5]. Особое внимание отводится сбору объек- тивной информации об индивидуальных особенностях земельных участков, включающих бонитет почв, специализацию хозяйств и др. [6], что позволяет формировать базу для оценки земли и проводить рациональную земельную политику [7].

На эффективность использования земельных участков влияют их размеры, форма, внутренняя структура, засоренность [8] и т. д. В мировой практике неправильная форма расценивается как недостаток территориального местоположения, затрудняющий эффективное использование рабочей силы, земельных, технических и других средств производства [9]. Для ее оптимизации необходимы: устранение недостатков землевладений и землепользований путем внесения изменений в их форму для приближения к эталону, в качестве которого выбран квадрат. 
В последние десятилетия в странах бывшего СССР происходит отчетливое разукрупнение сельскохозяйственных (далее - с.-х.) организаций путем создания мелких фермерских хозяйств, с.-х. предприятий, организации садоводческих товариществ. Небольшие хозяйства менее инерционны, чем крупные, однако на мелкоземелье возможны трудности с новыми технологиями, техническими средствами, посевным и посадочным материалом. Оптимум площади земельных участков имеет региональную специфику. К примеру, в США 157 тысяч крупных ферм (8 \% ) дают 76 \% продукции и $78 \%$ прибыли [10]. В Латвии около $80 \%$ участков (более 30 \% общей площади) имеют площади менее 2 га. Аналогичная ситуация в странах Азии и Европы $[11,12]$. В Центрально-Черноземной зоне России оптимум размера земельного участка составляет 10-14 тысяч гектаров [13].

Интегральной характеристикой плодородия почв является балл их бонитета [14]. В Томской области основная информация о нем содержится в материалах IY-го тура оценки земель, проведенного в 80-е гг. и актуализированная в ходе последующих туров. Балл бонитета был учтен в шкале среднерайонной нормы бесплатной передачи земли в собственность граждан [15]. В Томском районе размер доли составлял 7,9 га всех сельхозугодий (пашни сенокосы, пастбища), т. ч. 5,6 га пашни. В дальнейшем собственниками доли были сданы в аренду либо проданы, что привело к стихийному изменению площадей обрабатываемых земельных участков. Ситуация обострилась тем, что район, как и вся Томская область, относится к зоне рискованного земледелия [16] и площади земель, пригодных для производства продукции растениеводства, ограничены. Это диктует необходимость расценивать сельхозугодья «в качестве неприкосновенного жизненно наиболее важного земельного фонда» [17] и иметь о них полную объективную информацию, которая на данный момент отсутствует.
Цель исследования - анализ сложившегося распределения площадей земельных участков сельскохозяйственного назначения для выбора путей оптимизации их использования.

\section{Объекты и методы исследований}

Томский район занимает площадь 10,024 км². Расположен на юге Томской области в подтаежной зоне и частично в северной лесостепи (сосново-мелколиственная подзона) (рис. 1) [18, 19]. Площадь земель с.-х. назначения - $21 \%$ от территории района, население - 75154 человек (занятых преимущественно в сельскохозяйственном производстве).

Климат континентально-циклонический с продолжительной суровой снежной зимой и теплым коротким летом и с непродолжительными переходными и безморозными периодами. Характерны чередования циклонических и антициклонических типов погоды в течение всего года; значительные суточные и годовые амплитуды температуры воздуха; возвратные весенние и раннеосенние заморозки, ведущие к значительному сокращению вегетационного периода сельскохозяйственных культур ярового сева.

Зональными почвами являются дерново-подзолистые супесчаные, серые лесные, в поймах рек аллювиальные и аллювиально-болотные [19]. Они представлены по гранулометрическому составу преимущественно глинисто-пылеватым материалом, переходящим в более легкий суглинок. Почвам Томского района свойственны проблемы: переувлажнение, заплывание, низкая аэрируемость и позднее физическое созревание почв; низкое содержание гумуса и малая мощность гумусового горизонта, повышенная кислотность почв; биогенное загрязнение агроценозов.

Основными природныли рисками с.-х. производства являются: неустойчивость погодных условий, дефицит тепла, короткий вегетационный пе-

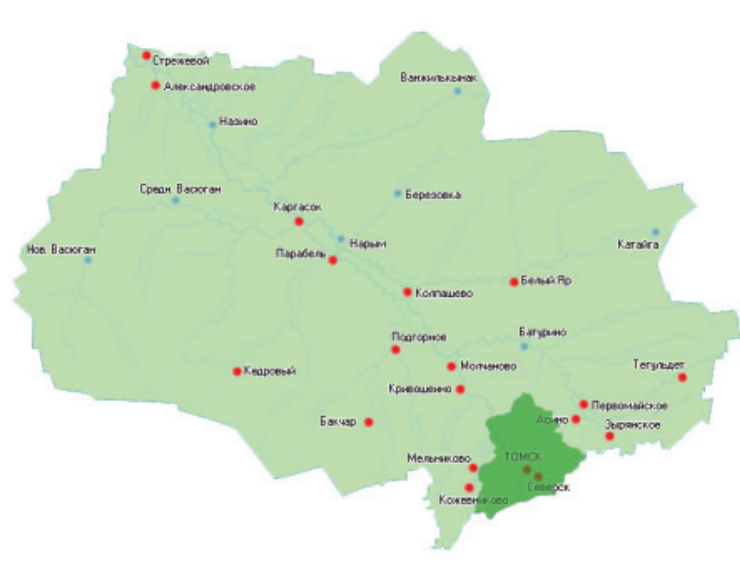

$a / a$

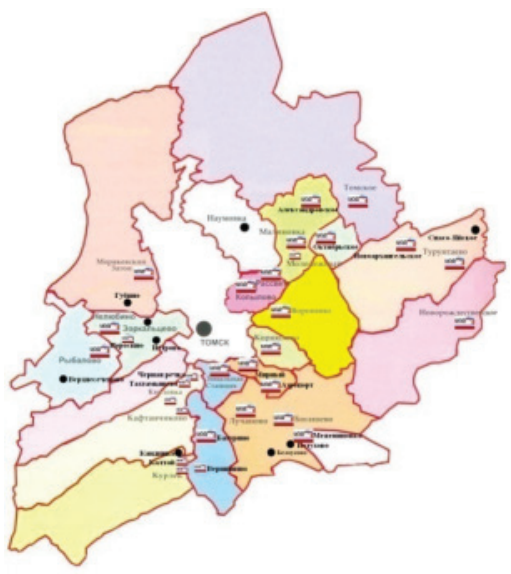

$\sigma / b$

Pис. 1. Расположение Томского района на карте Томской области (а) [20] и его основные населенные пункты (б) [21]

Fig. 1. Location of the Tomsk district on the map of the Tomsk region (a) [20] and its main settlements (b) [21] 
риод, высокий уровень заболоченности, закустаренности и залесённости территорий; основные $c 0^{-}$ ииальные риски: слабое развитие коммуникаций, инфраструктуры и дефицит специалистов.

Среди сельхозугодий Томского района площадью 174,375 тыс. га преобладают пашни (107,782 тыс. га), сенокосы $(37,47$ тыс. га) и пастбища $(24,203$ тыс. га). Имеются многолетние насаждения $(4,855$ тыс. га) и залежь $(0,065$ тыс. га) [17]. Общее число земельных участков - 3931. Для изучения взяты 3309 участков 25 хозяйств, имеющие непосредственное отношение к с.-х. производству.

Землеустроительные данные взяты с портала Росреестра [22] и с Публичной кадастровой карты [23]. Ландшафтные данные определены по материалам сервиса Google Earth [24]. Часть информации о состоянии и использовании земель получена от Федерального государственного бюджетного учреждения «Станция агрохимической службы «Томская»», за что авторы выражают благодарность ее директору д.с.-х.н. И.Б. Сорокину. Для анализа выбраны наиболее стабильные показатели почв, которые не подвержены сильной сезонной и территориальной динамике, но существенно влияют на плодородие и урожайность с.-х. культур (использование земель, балл бонитета почвы и положение в ландшафте).

Исходная информация потребовала унификации данных и увязки производственных названий с классификацией почв (1977 г.). Во-первых, из общей базы данных были исключены земельные участки под зданиями и сооружениями. Во-вторых, данные о типах почв были переклассифицированы с учетом «Шкалы оценки почв Томской области" [25]. Каждому земельному участку проставлен балл бонитета почв в зависимости от почвенной разновидности: максимальный - наиболее ценным темно-серым лесным (78 баллов) и серым лесным почвам (62 баллов); промежуточный светло-серым лесным глееватым, дерново-глеевым и дерново-глееватым, а также дерновым мелкоподзолистым (43-48 баллов); минимальный - дерновым глубоко- и неглубокоподзолистым (40 баллов) и дерновым глубоко-подзолистым (24 балла) почвам (табл. 1).

Положение земельных участков в ландшафтной системе координат охарактеризовано согласно ГОСТ 17.8.1.02-88 [26] и классификации M.А. Глазовской [27]. Положение земельных участков на выровненных водораздельных поверхностях оценено как элювиальное (автономное), на склонах - супераквальное, а также субаквальное в поймах рек.

$\mathrm{C}$ точки зрения целевого использования земель произведена перегруппировка полученных данных с помощью шкалы с.-х. ценности почв [19]. Bce почвы сведены в три агропроизводственные группы:

1) всестороннего хозяйственного использования, пригодные для развития полеводства и овоще- водства (при необходимости - для кормопроизводства);

2) кормовых угодий (в полеводстве и овощеводстве - после специальных мероприятий);

3) мелиоративного фонда, пригодные для с.-х. производства только после проведения мелиорации.

Таблица 1. Тип почв Толского района в сравнении с полученными данными и утвержденной шкалой оценки почв Томской области

Table 1. Soil type of Tomsk district in comparison with the obtained data and the approved scale of soil assessment of Tomsk region

\begin{tabular}{|l|l|c|}
\hline $\begin{array}{l}\text { Данные агрохимической } \\
\text { службы }\end{array}$ & \multicolumn{2}{|l|}{$\begin{array}{l}\text { Шкала оценки почв Томской области [25] } \\
\text { Rating scale of soils in Tomsk region [25] }\end{array}$} \\
\hline \multicolumn{2}{|c|}{ Аgrochemical service data }
\end{tabular}

Исходная агрохимическая база данных использования земель содержала разнородные характеристики: состояние поля - засорено, закустарено; вид использования - пашня, сенокосы, пастбища; культуры - кукуруза, рожь, пшеница т. д.; неиспользуемые для выращивания с.-х. продукции лес, болото, строения. Встречались группы земельных участков с видом использования "картофель», «свекла», «морковь», «капуста», в то время как имелась группа - «овощи», тематически объединяющая их. Соответственно, в новой классифи- 
кации все имеющиеся виды овощных культур и картофеля объединены в группу «овощи»; виды использования земельных участков «малина», «кусты», «сад»- в группу «садовые».

После устранения указанных несоответствий комплекс показателей был скорректирован следующим образом. Земельные участки исходной базы данных были объединены в 6 групп:

1) занятые строениями, сооружениями;

2) непригодные для ведения сельского хозяйства (лес, болото);

3) малопригодные для ведения сельского хозяйства (закустаренные и засоренные);

4) используемые для выращивания продукции кормового значения (злаковые - пшеница, кукуруза, рожь, ячмень; бобовые - горох, соя; овес, многолетние травы, зябь, пар, рапс);

5) используемые для выращивания садовых культур (малина, кусты);

6) занятые овощными культурами (капуста, морковь, свекла) и картофелем.

Группа 1 из статистического анализа была удалена ввиду ее исключительно технического назначения. С учетом корректировки предложен новый подход группирования земель c.-х. назначения по видам использования (табл. 2). Исходная база данных преобразована в таблицу, включающую 3309 земельных участков и 25 хозяйств Томского района со следующими показателями: наименование хозяйства, к которому он относится; площадь; тип почвы; балл бонитета и вид использования, и подготовлена для проведения статистического анализа.

Для оценки формы земельных участков произведен расчет коэффициентов их компактности как частного от деления периметров участков на периметры квадратов той же площади [28]. Определено максимальное и минимальное расстояния от земельных участков до населенных пунктов и производственных центров, поскольку от них зависят транспортные расходы и потери времени на холостые переезды. Взяты расстояния между двумя наиболее и наименее удаленными пунктами (по дорогам с учетом естественных препятствий). Аналогично рассчитаны максимальные расстояния от границ земельных участков до центральных усадеб в административных центрах района и до города Томска. Использован картографический материал ресурсов Google Earth и Публичной кадастровой карты Томской области.

Статистическая обработка данных проведена в пакете «Statistica» и программе «Excel» (корреляционный, регрессионный, детерминантный и кластерный виды анализов). Построена эмпирическая кривая распределения площадей земельных участков. Проверена гипотеза о нормальном распределении генеральной совокупности значений при уровне значимости $\mathrm{p}<0,05$. Проведен анализ характера распределения значений площадей [29]. Установлены максимальные и минимальные значения.
Таблица 2. Виды использования земельных участков Томского района, распределенные по группам

Table 2. Types of land use in the Tomsk district divided into groups

\begin{tabular}{|c|c|c|c|c|}
\hline \multicolumn{5}{|c|}{ Виды использования земельных участков/Types of land use } \\
\hline \multicolumn{3}{|c|}{$\begin{array}{c}\text { По с.-х. ценности } \\
\text { According to agricultural value [19] }\end{array}$} & \multirow{2}{*}{\multicolumn{2}{|c|}{\begin{tabular}{|c|} 
Предлагаемые \\
Proposed \\
Использование \\
Use \\
\end{tabular}}} \\
\hline $\begin{array}{c}\text { База данных } \\
\text { обследования }\end{array}$ & \begin{tabular}{|l|} 
Агропроизводст \\
венное значение
\end{tabular} & \multirow{2}{*}{$\begin{array}{c}\text { Группа } \\
\text { Group }\end{array}$} & & \\
\hline $\begin{array}{c}\text { земель } \\
\text { Land survey } \\
\text { database }\end{array}$ & $\begin{array}{c}\text { почв } \\
\text { Soil production } \\
\text { value }\end{array}$ & & Вид/Туре & $\begin{array}{c}\text { Группа } \\
\text { Group }\end{array}$ \\
\hline Кусты/Shrubs & $\mathrm{BXH} * / \mathrm{CEP} *$ & I & $\begin{array}{l}\text { Садовые } \\
\text { Garden }\end{array}$ & 5 \\
\hline $\begin{array}{l}\text { Болото } \\
\text { Swamp }\end{array}$ & $\begin{array}{l}\text { Болотные } \\
\text { и торфяные } \\
\text { Marsh and peat }\end{array}$ & III & $\begin{array}{l}\text { Непригодные } \\
\text { Unfit }\end{array}$ & 2 \\
\hline Горох/Pea & $\mathrm{BXH} * / \mathrm{CEP} *$ & I & $\begin{array}{l}\text { Kормовые } \\
\text { Fodder }\end{array}$ & 4 \\
\hline $\begin{array}{l}\text { Закустарено } \\
\text { Bushed }\end{array}$ & \multirow{2}{*}{$\begin{array}{l}\mathrm{H} / \mathrm{A}^{* *} \\
\text { No data }\end{array}$} & \multirow{2}{*}{$\begin{array}{c}\mathrm{H} / д \\
\text { No data }\end{array}$} & \multirow{2}{*}{$\begin{array}{l}\text { Малопригод- } \\
\text { ные } \\
\text { of little use }\end{array}$} & \multirow{2}{*}{3} \\
\hline $\begin{array}{l}\text { Засорено } \\
\text { Littered }\end{array}$ & & & & \\
\hline $\begin{array}{l}\text { Зерносмесь } \\
\text { Grain mixture }\end{array}$ & \multirow{2}{*}{$\begin{array}{l}\text { Кормового значения } \\
\text { Feed value }\end{array}$} & II & \multirow{2}{*}{$\begin{array}{l}\text { Кормовые } \\
\text { Fodder }\end{array}$} & \multirow[t]{2}{*}{4} \\
\hline Зябь/Chaff & & \multirow{3}{*}{ I } & & \\
\hline $\begin{array}{l}\text { Капуста } \\
\text { Cabbage } \\
\end{array}$ & \multirow{2}{*}{$\mathrm{BXH} * / \mathrm{CEP} *$} & & Овощные & \\
\hline $\begin{array}{l}\text { Картофель } \\
\text { Potatoes }\end{array}$ & & & Vegetable & 6 \\
\hline $\begin{array}{l}\text { Кукуруза } \\
\text { Corn } \\
\end{array}$ & $\begin{array}{l}\text { Кормового значения } \\
\text { Feed value } \\
\end{array}$ & \multirow{2}{*}{ II } & $\begin{array}{l}\text { Koрмовые } \\
\text { Fodder } \\
\end{array}$ & 4 \\
\hline Jec/Forest & $\begin{array}{l}\mathrm{H} / \text { д } \\
\text { No data }\end{array}$ & & $\begin{array}{l}\text { Непригодные } \\
\text { Unfit }\end{array}$ & 2 \\
\hline $\begin{array}{l}\text { Малина } \\
\text { Raspberries }\end{array}$ & $\mathrm{BXH}^{*} / \mathrm{CEP} *$ & I & $\begin{array}{l}\text { Садовые } \\
\text { Garden }\end{array}$ & 5 \\
\hline $\begin{array}{l}\text { Многолетние } \\
\text { травы } \\
\text { Perennial } \\
\text { herbs }\end{array}$ & $\begin{array}{l}\text { Кормового значения } \\
\text { Feed value }\end{array}$ & II & $\begin{array}{l}\text { Кормовые } \\
\text { Fodder }\end{array}$ & 4 \\
\hline $\begin{array}{l}\text { Морковь } \\
\text { Carrot }\end{array}$ & $\mathrm{BXH} * / \mathrm{CEP} *$ & I & $\begin{array}{l}\text { Овощные } \\
\text { Vegetable }\end{array}$ & 6 \\
\hline $\begin{array}{l}\text { Oвес } \\
\text { Oats }\end{array}$ & $\begin{array}{l}\text { Кормового значения } \\
\text { Feed value }\end{array}$ & II & $\begin{array}{l}\text { Kормовые } \\
\text { Fodder }\end{array}$ & 4 \\
\hline $\begin{array}{l}\text { Овощи } \\
\text { Vegetables }\end{array}$ & \multirow{3}{*}{$\mathrm{BXH} * / \mathrm{CEP} *$} & \multirow{3}{*}{ I } & $\begin{array}{l}\text { Овощные } \\
\text { Vegetable }\end{array}$ & 6 \\
\hline Пар/Steam & & & \multirow{2}{*}{$\begin{array}{l}\text { Кормовые } \\
\text { Fodder }\end{array}$} & \multirow[b]{2}{*}{4} \\
\hline $\begin{array}{l}\text { Пашня } \\
\text { Arable land }\end{array}$ & & & & \\
\hline $\begin{array}{l}\text { Поле засорено } \\
\text { Field littered }\end{array}$ & \multicolumn{2}{|l|}{$\begin{array}{l}\mathrm{H} / \text { д } \\
\text { No data }\end{array}$} & $\begin{array}{l}\text { Малопригодные } \\
\text { of little use }\end{array}$ & 3 \\
\hline \begin{tabular}{l|} 
Пшеница \\
Wheat
\end{tabular} & $\mathrm{BXH} * / \mathrm{CEP} *$ & I & \multirow{3}{*}{$\begin{array}{l}\text { Кормовые } \\
\text { Fodder }\end{array}$} & \multirow{3}{*}{4} \\
\hline Рапс/Rape & $\begin{array}{l}\text { Koрмового значения } \\
\text { Feed value }\end{array}$ & II & & \\
\hline Рожь/Rye & \multirow{4}{*}{$\mathrm{BXH} * / \mathrm{CEP} *$} & \multirow{4}{*}{ I } & & \\
\hline Сад/Garden & & & $\begin{array}{l}\text { Садовые } \\
\text { Garden }\end{array}$ & 5 \\
\hline Свекла/Beet & & & $\begin{array}{l}\text { Овощные } \\
\text { Vegetable }\end{array}$ & 6 \\
\hline Соя/Soy & & & $\begin{array}{l}\text { Kopмовые } \\
\text { Fodder }\end{array}$ & 4 \\
\hline $\begin{array}{l}\text { Строения } \\
\text { Buildings }\end{array}$ & \multicolumn{2}{|l|}{$\begin{array}{l}\mathrm{H} / \text { д } \\
\text { No data }\end{array}$} & $\begin{array}{l}\text { Строения } \\
\text { Buildings }\end{array}$ & 1 \\
\hline $\begin{array}{l}\text { Ячмень } \\
\text { Barley }\end{array}$ & $\mathrm{BXH} * / \mathrm{CEP} *$ & I & $\begin{array}{l}\text { Кормовые } \\
\text { Fodder }\end{array}$ & 4 \\
\hline
\end{tabular}

*Примечание: *-всестороннего хозяйственного назначения; ** нет данных.

* Note: *-uniform economic purpose; $* *$ - no data available. 
Таблииа 3. Территориальные характеристики 25 хозяйств Томского района: площадь (га), число участков (ед.), число участков на га (ед./га), средняя площадь участка (га)

Table 3. Territorial characteristics of 25 farms of Tomsk region: area (ha), number of plots (units), number of plots per hectare (units/ha), average area of the plot (ha)

\begin{tabular}{|c|c|c|c|c|}
\hline $\begin{array}{l}\text { Хозяйство } \\
\text { Farm }\end{array}$ & $\begin{array}{c}\text { Площадь, га } \\
\text { Area, ha }\end{array}$ & 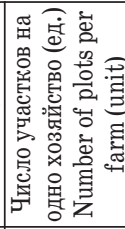 & 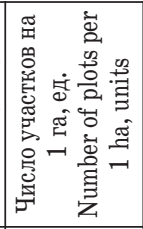 & 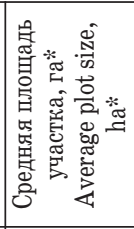 \\
\hline $\begin{array}{l}\text { Батуринское } \\
\text { Baturinskoe }\end{array}$ & 1506,4 & 81 & 0,054 & $18,60 \pm 0,57$ \\
\hline $\begin{array}{l}\text { Вершининское } \\
\text { Vershininskoe }\end{array}$ & 4247,7 & 212 & 0,050 & $20,04 \pm 0,33$ \\
\hline Калтай/Caltay & 2958,7 & 148 & 0,050 & $19,99 \pm 0,36$ \\
\hline $\begin{array}{l}\text { Кандинская } \\
\text { птицефабрика } \\
\text { Kandinskaya } \\
\text { poultry farm }\end{array}$ & 734,6 & 38 & 0,052 & $19,33 \pm 0,60$ \\
\hline $\begin{array}{l}\text { Кафтанчиково } \\
\text { Kaftanchikovo }\end{array}$ & 2958,0 & 157 & 0,053 & $18,84 \pm 0,41$ \\
\hline $\begin{array}{l}\text { Межениновское } \\
\text { Mezheninovskoe }\end{array}$ & 2536,5 & 138 & 0,054 & $18,38 \pm 0,50$ \\
\hline OПХ/OPKh & 9885,5 & 502 & 0,051 & $19,69 \pm 0,20$ \\
\hline ГСК/GSK & 240,4 & 19 & 0,079 & $12,65 \pm 0,20$ \\
\hline $\begin{array}{l}\text { Кисловское } \\
\text { Kislovskoe }\end{array}$ & 1793,1 & 91 & 0,051 & $19,70 \pm 0,60$ \\
\hline Петрово/Petrovo & 1801,1 & 92 & 0,051 & $19,58 \pm 0,60$ \\
\hline \begin{tabular}{|l} 
Степановский \\
Stepanovsky
\end{tabular} & 1233,9 & 64 & 0,052 & $19,28 \pm 0,70$ \\
\hline $\begin{array}{l}\text { Томская } \\
\text { птицефабрика } \\
\text { Tomsk poultry farm }\end{array}$ & 1669,7 & 95 & 0,057 & $17,58 \pm 0,70$ \\
\hline Томь/Tom & 1709,2 & 90 & 0,053 & $18,99 \pm 0,70$ \\
\hline $\begin{array}{l}\text { Туганская } \\
\text { птицефабрика } \\
\text { Tugansk poultry } \\
\text { farm }\end{array}$ & 620,3 & 32 & 0,052 & $19,38 \pm 1,06$ \\
\hline $\begin{array}{l}\text { Кузовлевский } \\
\text { Kuzovlevsky }\end{array}$ & 969,6 & 192 & 0,198 & $5,05 \pm 0,60$ \\
\hline Октябрь/Oktyabr & 6185,0 & 321 & 0,052 & $19,27 \pm 0,25$ \\
\hline Родина/Rodina & 4167,1 & 214 & 0,051 & $19,47 \pm 0,29$ \\
\hline $\begin{array}{l}\text { Рыбаловское } \\
\text { Rybalovskoe }\end{array}$ & 8388,8 & 419 & 0,050 & $20,02 \pm 0,22$ \\
\hline $\begin{array}{l}\text { Пойменный } \\
\text { Poymenny }\end{array}$ & 1521,2 & 81 & 0,053 & $18,78 \pm 0,43$ \\
\hline Томский/Tomsk & 7436,3 & 401 & 0,054 & $18,54 \pm 0,30$ \\
\hline $\begin{array}{l}\text { Сибиряк } \\
\text { Sibiryak }\end{array}$ & 3538,4 & 190 & 0,054 & $18,62 \pm 0,46$ \\
\hline Победа/Pobeda & 8307,2 & 102 & 0,0123 & $81,44 \pm 2,3$ \\
\hline $\begin{array}{l}\text { Новоархангельское } \\
\text { Novoarkhangelskoe }\end{array}$ & 2849,0 & 36 & 0,0126 & $79,14 \pm 2,5$ \\
\hline 3aps/Zarya & 9162,6 & 134 & 0,0146 & $68,38 \pm 2,4$ \\
\hline $\begin{array}{l}\text { Мазаловский } \\
\text { Mazalovsky }\end{array}$ & 6218,9 & 82 & 0,0132 & $75,84 \pm 2,2$ \\
\hline $\begin{array}{l}\text { Среднее значение } \\
\text { Average value }\end{array}$ & $3705 \pm 2959$ & $157 \pm 127$ & $0,053 \pm 0,034$ & $20,4 \pm 6,2$ \\
\hline $\begin{array}{l}\text { Доверительный } \\
\text { интервал } \\
\text { Confidence interval }\end{array}$ & 1233,89 & 53,29 & 0,014 & 9,18 \\
\hline $\begin{array}{l}\text { Максимум } \\
\text { Maximum }\end{array}$ & 9885,5 & 502 & 0,198 & 81,4 \\
\hline $\begin{array}{l}\text { Минимум } \\
\text { Minimum }\end{array}$ & 240,4 & 19 & 0,0123 & 5,05 \\
\hline
\end{tabular}

*Примечание: при $p<0,001$.

* Note: at $p<0,001$.
С помощью иерархического кластерного анализа пакета Orange выявлены границы сложившихся групп земельных участков («Малые», «Средние» и «Крупные»). Выделено пять категорий части, разделы, подразделы, группы, подгруппы. Части выборки разделены по масштабу («Гигантские», «Очень крупные», «Крупные», «Средние», «Малые», «Очень малые» и «Сверхмалые»). С помощью критерия стандартизации земельные участки охарактеризованы как «Нестандартизованные», «Средне стандартизованные», «Стандартизованные», «Стандартные». Подразделы разделены по степени отклонения от стандарта ( «Меньше», «Стандарт», «Больше»); группы внутри них по размерам ( «Большой», «Средний», «Мелкий»); подгруппы - по принадлежности к хозяйствам.

\section{Результаты и обсуждение}

Земельные участки хозяйствующих субъектов Томского района разнообразны по площади и составу и назначению (табл. 3). Площади хозяйств различаются в разы и даже в десятки раз. К примеру, площадь ОПХ равна 9885,5 га, ГСК - 240,4 га (в 41 раз меньше) (табл. 4). Минимальные площади хозяйств ГСК $(12,65$ га) и «Кузовлевский» $(5,05$ га) объяснимы их использованием для научно-исследовательских целей и выращивания растений мелкоделяночным способом. Максимальные площади занимает фирма «ОПХ» $(9885,5$ га), а также с.-х. производственные кооперативы «Рыбаловский» $(8388,8$ га) и «Томский» $(7436,3$ га).

В одном хозяйстве в среднем находятся 157,24 участка; максимум - 502, минимум - 19 (в 26 раз меньше). На 1 га земель приходится 0,053 ед./га; максимум - 0,198 ед./га, минимум 0,012 ед./га (в 16 раз меньше). Средняя площадь земельного участка в Томском районе составляет $20,4 \pm 6,2$ при $\mathrm{p}<0,001$ га; максимум - 81,4 га, минимум - 19 га (в 4 раза меньше). В некоторых хозяйствах (Победа, Новоархангельское, Заря, Мазаловский) участки относительно велики (выше среднего значения в 3-4 раза). Выборка по размерам хозяйств, числу участков, площадных размеров участков крайне неоднородна. Максимальные относительные различия отмечены для площади отдельных хозяйств, минимальные - для площади участков.

Статистический анализ площадей земельных участков выявил бимодальный вид их распределения. Максимальное накопление частот отмечено в интервале 18-22 га (52 \% общего количества частот), среднее - в интервале 4-6 га (5\% частот) при фоновом значении 1-2 \% (рис. 2).

Среди земельных участков с.-х. назначения в Томском районе преобладают участки площадью 15-20 га (43\%, т. е. 1420 участков). Примерно треть участков имеет площадь в 20-25 га (около $30 \%, 980$ участков), около $14 \%$ - 10-15 га (460 участков). На гистограмме распределения площадей участков выделены три выборки:

1) «Малые», от 0 до $<10$; 


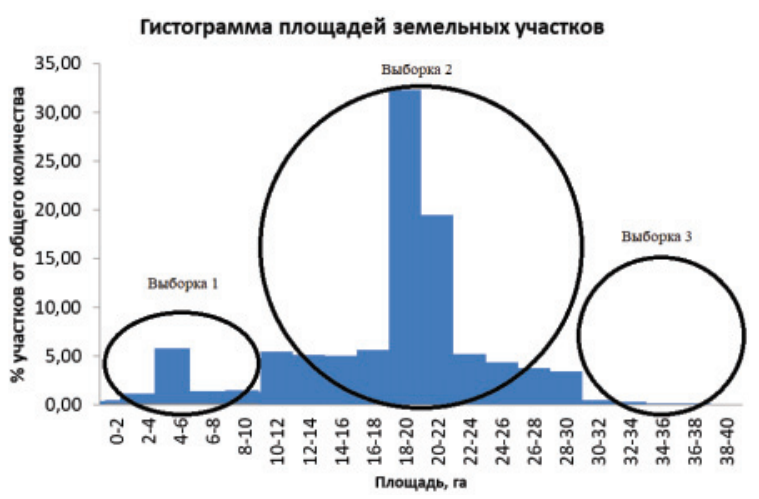

Рис. 2. Гистогралма распределения площадей участков земель с.-х. назначения в Толском районе разделена по разлерам на три выборки: 1) «Малые»; 2) «Средние»; 3) «Кру пные» земельные участки

Fig. 2. Histogram of area distribution of agricultural land in the Tomsk district is divided by size into three samples: 1) «Small»; 2) «Medium»; 3) «Large» lands

2) «Средние», от 10 до $<30$;

3) «Крупные», от 30 до 38,5 .

Они существенно (в 5-6 раз) различаются по числу случаев. Для более детального анализа каждая выборка рассмотрена отдельно (рис. 3). В выборках 1 и 2 наблюдаются интервалы со значительным накоплением частот. В выборке 3 они отсутствуют. Выборка 1 (314 участка) существенно отличается от нормального распределения - коэффициент Колмогорова-Смирнова незначителен и не достоверен $\mathrm{p}>0,1$, коэффициент вариации - $22,4 \%$. Выборка 2 содержит 3136 участков. Среднее значение их площади составляет $19,65 \pm 0,29$ га, стандартное отклонение - 4,07 га, коэффициент вариации 20,7 \% . Выборка 3 (40 участков) бимодальна. Среднее значение площади участка равно $32,6 \pm 1,6$ га, медиана - 32 га, стандартное отклонение - 2,4 га, коэффициент вариации - 7,53 \% .

Коэффициент асимметрии (третий, центральный момент отклонения от средней нормального распределения случайной величины) отражает форму сдвига выборки право/лево относительно среднего значения, эксцесс (четвертый центральный момент) характеризует сжатие относительно формы нормального распределения (верх/низ). У выборки 1 (рис. $3, a$ ) имеется сдвиг влево и положительный коэффициент асимметрии $(0,16)$; у выборки 2 (рис. 3, б) - незначительный отрицательный $(-0,07)$; у выборки 3 - очень высокий коэффициент сдвига влево $(0,78)$. Эксцесс для всех выборок очень высок, для третьей выборки он отрицателен и не достоверен, так как ошибка больше абсолютного значения $(-0,43<0,73)$. Исходя из анализа значений асимметрии и эксцесса, можно сделать выводы, что выборки существенно отклоняются по форме от нормального распределения случайной величины; имеют малый по величине и недостоверный коэффициент Колмагорова-Смирнова; их распределение нельзя считать нормальным. Выборка 3 (рис. 3, в) бимодальна. Следовательно, выборки площадей земельных участков хозяйств Томского района носят неслучайный характер и сопровождаются накоплением в отдельных интервалах, поэтому для оценки влияния факторов использованы непараметрические критерии.

Проведен иерархической анализ земельных участков Томского района по площади хозяйства путем их разбиения на кластеры и получения в каждом кластере расчетных площадей (рис. 4). По площадным размерам выделяются две части выборки - «Крупные» и «Средние и малые». В часть «Крупные» входят подчасти: «Гигантские» (голубой цвет), «Очень крупные» (красный) и «Крупные (желтый)». Первая часть полностью не стандартизована. Граница между частями проходит по величине площади больше 24,8 га. Вторая часть выборки содержит площади меньше или равные этому значению и разделяется на две подчасти: «Средние», «Малые» (бурый цвет). Подчасть «Средние» дробится на три раздела: «Мало стандартизованные» (голубой) - 10,1-13,8 га, «Средне стандартизованные» (фиолетовый) 13,9-17,8 га и «Стандартные» (желтый) 19,5-24,8 га. Подчасть «Малые» делится на две группы: «Стандартизованные» - 2,3-5,6 га и «Нестандартизованные больше стандарта» 5,7-7,8 га, а также «Нестандартизованные меньше стандарта» - 2,3-0,99 га. Подразделы делятся

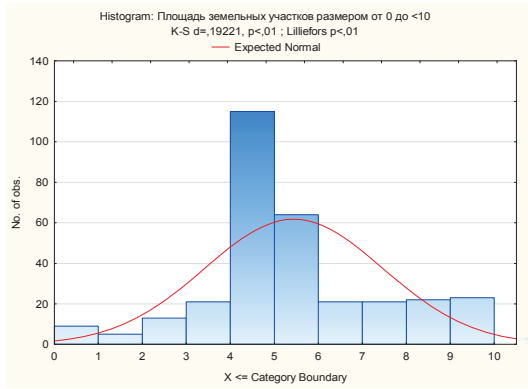

$a / a$

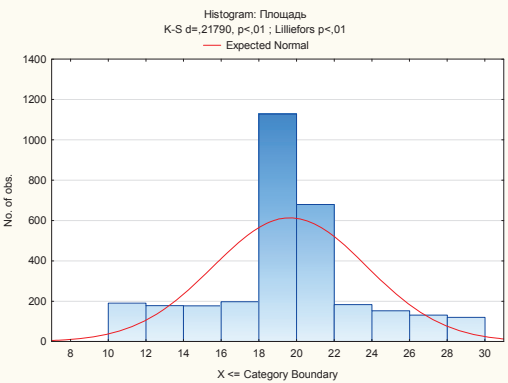

$\sigma / b$

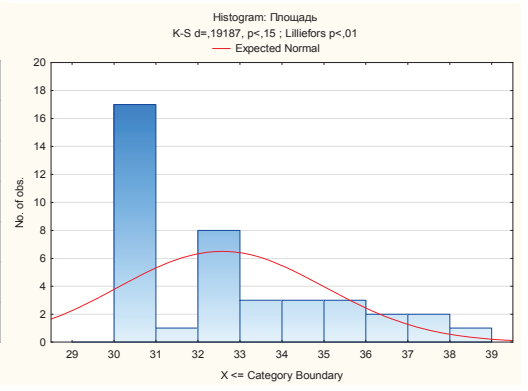

$B / c$

Рис. 3. Гистограмлы распределения размеров площади (га) участков земель с.-х. назначения выборок: а) от 0 до <10 («Малье»; б) от 10 до <30 («Средние»); в) более 30 га («Крупные»)

Fig. 3. Histograms of size distribution of the area ( ha ) of agricultural land plots samples: a) from 0 to $<10$ ( «Small»); b) from 10 to $<30$ ( «Medium»); c) more than 30 hectares ( «Large») 


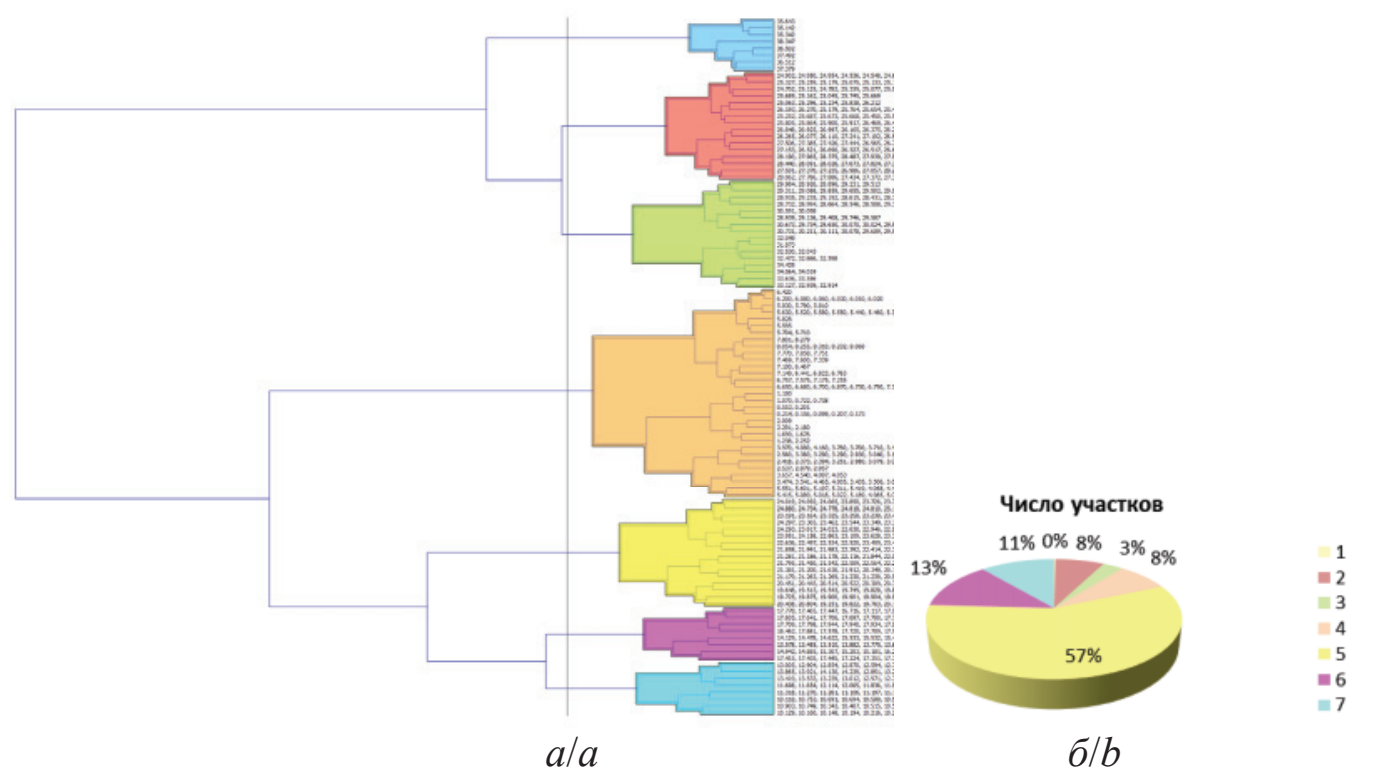

Pис. 4. Применение иерархического кластерного анализа для классификации основных разлерных групп зелельных участков Томского района (а) и распределение числа земельных участков в хозяйствах Томского района по группам (га): 1) 35,643-37,378; 2) $24,90-27,32$; 3 ) $29,98-32,91$; 4 ) 1,10-8,07; 5 ) 19,90-24,90; 6 ) 13,46-17,78; 7) 13,01-10,20 (б)

Fig. 4. Application of hierarchical cluster analysis for classification of the main size groups of land plots of the Tomsk district (a) and distribution of the number of land plots in the farms of Tomsk district in groups (ha): 1) 35,643-37,378; 2) 24,90-27,32; 3) 29,98-32,91; 4) $1,10-8,07 ; 5) 19,90-24,90 ; 6$ ) $13,46-17,78 ; 7$ ) $13,01-10,20$ (b)

на группы. Внутри подраздела «Стандартные» выделяются 3 группы - «MS-S» $(19,82-20,51$ га), «M»-19,82-22,6 га, «L»-22,6-24,9 га. Подгруппы делятся по принадлежности к хозяйству. Например, к стандартным «М» относятся ОПХ, Картанчиково, Сибиряк, Кандинская.

Согласно предложенной классификации, выделены семь неравнозначных групп по площадям земельных участков. Группа 1 содержит 8 участков, группа 2 - 257, группа 3 - 106, группа $4-275$, группа 5 - 2002, группа 6 - 451, группа 7 391 участок. Явно выделяется наименьшая группа 1 с размерами участков 35,14-38,34 га и наибольшая группа 5 с размерами участков $18,45-24,56$ га. Диапазон изменчивости площади земельного участка составляет в группе 1 $35,643-37,378$ га; в группе 2 - 24,90-27,32 га; в группе 3 - 29,98-32,91 га; в группе 4 1,10-8,07 га; в группе 5 19,90-24,90 га; в группе 6 - 13,46-17,78 га в группе $7-13,01-10,20$ га. Около $60 \%$ земельных участков имеют площади от 19,90-24,90 га. Близкое представительство имеют группы 6 и 7 (11 и $13 \%$ соответственно). Доля остальных групп не превышает $10 \%$ (рис. 4).

Выявление факторов, влияющих на площадь зелельных участков в Толскол районе. В качестве факторов, потенциально оказывающих влияние на площади земельных участков, рассмотрены:

- хозяйственное назначение;

- бонитет почв;

- тип почв (серые лесные, аллювиальные, светросерые, аллювиальные луговые, темно-серые, дерново-глубокоподзолистые, дерново-глееватые, дерново-глеевые);
- положение земельных участков в ландшафте (элювиальное, трансэлювиальное, субаквальное (пойма).

Для оценки влияния факторов на площади земельных участков использован критерий Краскела-Уоллиса для независимых выборок (выборки независимы, т. к. оценка бонитета почв проводится независимо от определения границ земельного участка на основе карты почвенных типов, агрохимических анализов и продуктивности полей).

Установлено, что распределение числа наблюдений по факторам неравномерно и не относится к нормальному распределению случайных величин.

Хозяйственное назначение. Анализ средних значений площадей земельных участков, различных по хозяйственному назначению, выявил их достаточно близкие значения от 18,12 га (группа 2) до 20, 44 га (группа 6). Отмечена тенденция роста площади с ростом балла хозяйственного назначения. Выявлены достаточно близкие показатели площадей земельных участков, различных по хозяйственному назначению от 18,12 га (группа 2) до 20, 44 га (группа 6). Отмечена тенденция роста площади участка с ростом балла хозяйственного назначения, однако различия между группами недостоверны ввиду больших величин среднеквадратичных отклонений от 12 до 17.

К группе 2 отнесены 1211 участков (35\%), к группе 3 - 235 участков $(9 \%)$, к группе 4 1723 участка (49\%), к группе 5 - 240 участков (7\%), к группе 6 - 81 участок (2\%). Таким образом, в Томском районе площади непригодные и мало пригодные (закустаренные) для ведения сельского хозяйства составляют $44 \%$, кормовыми 
культурами занята почти половина земель, садовыми и овощными - 7 и $2 \%$ соответственно.

Бонитет почв. Практически не встречаются объекты в интервале бонитета почв 32-40 и 56-64 баллов. Максимально распространены почвы с баллом бонитета, равным 64-72 (1640 участков). Среднее положение в рейтинге занимают почвы с баллом 48-56 (600 участков). В 2,0-2,5 раза меньше участков с почвами, имеющими баллы 24-32 и 40-48 (по 280 участков) и 72-80 (320 участков). Средние значения площади с разными баллами бонитета укладываются в диапазон 15-20 га, но среднеквадратичные отклонения существенно различаются. В целом для выборки они составляют до двух единиц, за исключением участков с баллами бонитета $43( \pm 15), 44( \pm 12)$ и $65( \pm 10)$ единицы.

Tun почв. Среди почв земельных участков с.-х. назначения Томского района доминируют серые лесные. Ими характеризуются 1600 участков $(45 \%)$. Светло-серые лесные глееватые почвы обнаружены на примерно 500 участках (14\%). Аллювиальные дерновые, темно-серые лесные, дерновые глубоко- и неглубокоподзолистые, дерновые мелкоподзолистые свойственны менее чем 400 участкам (11\%). Дерновые глубоко-подзолистые, дерново-глеевые и дерново-глееватые почвы практически отсутствуют.

Положение зелельных участков с.-х. назначе ния в ландшафте в основном элювиальное $(2500$ участков, $72 \%$ ) и трансэлювиальное (750 участков, $21 \%$ ). Менее сотни участков находятся в супераквальном положении. Очень редко встречаются участки в субаквальном типе ландшафта. Выше отмечено ненормальное распределение земельных участков по площади, поэтому далее использованы непараметрические виды анализа. Для оценки влияния на площадь земельных участков типа и бонитета почв, их положения в ландшафте, а также хозяйственного назначения участков использован критерий Краскела-Уоллиса для независимых выборок. Ранее путем анализа иерархической структуры площади нарушенных участков показано, что размеры неоднородностей почвенного покрова обусловлены внешними и внутренними факторами, а размеры земельных участков являются инструментом для выявления природных и антропогенных факторов [30].

Площади участков земель с.-х. назначения независимы от природных факторов, поэтому объяснить выявленные различия можно лишь осознанным либо спонтанным регулированием со стороны землепользователей. В Томском районе даже при отсутствии нормативов $73 \%$ земельных участков имеют площади 15-25 га, при том, что 20 га оптимальны с точки зрения эффективного применения технических средств [6, 28]. Следовательно, есть основания говорить об обусловленности размеров земельных участков технико-экономическими причинами.
Удаленность хозяйства. Проведен анализ зависимости площади хозяйства от числа земельных участков, минимального и максимального расстояния до границ земельного участка (по дорогам) от центральной усадьбы в административном центре района и от г. Томска. Результаты измерений по публичной кадастровой карте приведены в табл. 4.

Таблица 4. Удаленность хозяйств Толского района от административных иентров и города Томска

Table 4. Remoteness of the farms of the Tomsk district from the administrative centers and the city of Tomsk

\begin{tabular}{|c|c|c|c|c|c|}
\hline \multirow{3}{*}{$\begin{array}{c}\text { Наименование } \\
\text { хозяйства } \\
\text { Farm name }\end{array}$} & \multicolumn{5}{|c|}{ Расстояние от, км/Distance from, km } \\
\hline & \multicolumn{2}{|c|}{$\begin{array}{c}\text { административ- } \\
\text { ного центра } \\
\text { administrative } \\
\text { center }\end{array}$} & \multicolumn{2}{|c|}{$\begin{array}{l}\text { Tомска } \\
\text { Tomsk }\end{array}$} & \multirow{2}{*}{\begin{tabular}{|c} 
Административ- \\
ный центр \\
Administrative \\
center
\end{tabular}} \\
\hline & $\begin{array}{l}\text { Мин. } \\
\text { min }\end{array}$ & $\begin{array}{l}\text { Макс. } \\
\max \end{array}$ & $\begin{array}{l}\text { Мин. } \\
\text { min }\end{array}$ & $\begin{array}{c}\text { Макс. } \\
\max \end{array}$ & \\
\hline $\begin{array}{l}\text { Батуринское } \\
\text { Baturinskoe }\end{array}$ & 0,1 & 6,4 & 16,3 & 25,2 & \multirow{2}{*}{$\begin{array}{l}\text { Батурино } \\
\text { Baturino }\end{array}$} \\
\hline $\begin{array}{l}\text { Вершининское } \\
\text { Vershininskoe } \\
\end{array}$ & 2,4 & 10,9 & 27,6 & 36,1 & \\
\hline ГСК/GSK & 2,3 & 3,6 & 4,8 & 6,1 & $\begin{array}{l}\text { Зональная Станция } \\
\text { Zonalnaya village }\end{array}$ \\
\hline Калтай/Caltai & 1,6 & 16,7 & 15,7 & 30,8 & Калтай/Kaltay \\
\hline $\begin{array}{l}\text { Кандинская } \\
\text { птицефабрика } \\
\text { Kandinskaya } \\
\text { poultry farm }\end{array}$ & 3,8 & 9,5 & 5,8 & 11,8 & $\begin{array}{l}\text { Копылово } \\
\text { Kopylovo }\end{array}$ \\
\hline $\begin{array}{l}\text { Кафтанчиково } \\
\text { Kaftanchikovo }\end{array}$ & 0,6 & 13,0 & 16,1 & 27,4 & \multirow{2}{*}{$\begin{array}{l}\text { Кафтанчиково } \\
\text { Kaftanchikovo }\end{array}$} \\
\hline $\begin{array}{l}\text { Кисловское } \\
\text { Kislovskoe }\end{array}$ & 9,6 & 24,8 & 7,8 & 23,7 & \\
\hline $\begin{array}{l}\text { Межениновское } \\
\text { Mezheninovskoe }\end{array}$ & 0,8 & 13,4 & 21,5 & 34,1 & $\begin{array}{l}\text { Mежениновка } \\
\text { Mezheninovka }\end{array}$ \\
\hline $\begin{array}{l}\text { Октябрь } \\
\text { Oktyabr }\end{array}$ & 1,5 & 16,2 & 15,6 & 30,5 & \begin{tabular}{|l} 
Зоркальцево \\
Zorkaltsevo
\end{tabular} \\
\hline $\mathrm{O \Pi X} / \mathrm{OPH}$ & 3,1 & 21,8 & 17,1 & 35,8 & $\begin{array}{l}\text { Богашево } \\
\text { Bogashevo }\end{array}$ \\
\hline $\begin{array}{l}\text { Петрово } \\
\text { Petrovo }\end{array}$ & 6,9 & 13,3 & 6,8 & 18,8 & $\begin{array}{l}\text { Северск } \\
\text { Seversk }\end{array}$ \\
\hline $\begin{array}{l}\text { Пойменный } \\
\text { Poymenny }\end{array}$ & 12,2 & 15,7 & 34,8 & 38,3 & \multirow{2}{*}{$\begin{array}{l}\text { Зоркальцево } \\
\text { Zorkaltsevo }\end{array}$} \\
\hline Родина/Rodina & 3,1 & 16,6 & 20,5 & 34,1 & \\
\hline $\begin{array}{l}\text { Рыбаловское } \\
\text { Rybalovskoe }\end{array}$ & 2,0 & 18,1 & 26,1 & 53,7 & $\begin{array}{l}\text { Рыбалово } \\
\text { Rybalovo }\end{array}$ \\
\hline $\begin{array}{l}\text { Сибиряк } \\
\text { Sibiryak }\end{array}$ & 0,3 & 11,1 & 24,9 & 40,1 & $\begin{array}{l}\text { Наумовка } \\
\text { Naumovka }\end{array}$ \\
\hline $\begin{array}{l}\text { Степановский } \\
\text { Stepanovsky }\end{array}$ & 1,6 & 7,1 & 4,3 & 9,8 & $\begin{array}{l}\text { Зональная Станция } \\
\text { Zonalnaya village }\end{array}$ \\
\hline $\begin{array}{l}\text { Томская } \\
\text { птицефабрика } \\
\text { Tomsk poultry } \\
\text { farm }\end{array}$ & 5,6 & 15,2 & 18,8 & 24,6 & $\begin{array}{l}\text { Воронино } \\
\text { Voronino }\end{array}$ \\
\hline Томский/Tomsk & 1,5 & 16,2 & 33,2 & 47,3 & $\begin{array}{l}\text { Октябрьское } \\
\text { Oktyabrskoe }\end{array}$ \\
\hline Томь/Tom & 5,6 & 9,6 & 3,2 & 12 & $\begin{array}{l}\text { Кафтанчиково } \\
\text { Kaftanchikovo }\end{array}$ \\
\hline $\begin{array}{l}\text { Туганская } \\
\text { птицефабрика } \\
\text { Tugansk poultry } \\
\text { farm }\end{array}$ & 4,4 & 7,6 & 12,3 & 14,6 & \multirow[t]{2}{*}{$\begin{array}{l}\text { Копылово } \\
\text { Kоруlovo }\end{array}$} \\
\hline $\begin{array}{l}\text { Кузовлевский } \\
\text { Kuzovlevsky }\end{array}$ & 4,1 & 7,0 & 17,8 & 20,6 & \\
\hline
\end{tabular}


Расстояния от административного центра до границы земельного участка очень разнородны. Они составляют: минимальное 0,1-12,2 км; максимальное 3,6-24,8 км. Расстояние от г. Томска изменяется в пределах: минимальное $3,2-33,2$ км; максимальное 6,1-53,7 км. Выявлена достоверная корреляционная зависимость средней силы: положительная между площадью земельного участка и ее периметром $(\mathrm{r}=0,7$ при $\mathrm{p}<0,05)$ и отрицательная между площадью земельного участка и коэффициентом компактности $(\mathrm{r}=-0,7$ при $\mathrm{p}<0,05)$.

Площадь хозяйства практически прямо пропорциональная числу участков, входящих в ее состав $(\mathrm{r}=0,903$ при $\mathrm{p}<0,05)$. Регрессионная модель, описывающая эту зависимость, представлена уравнением (1):

$$
\mathrm{y}=0,0488 \mathrm{x}+16,746, \text { при } \mathrm{R}^{2}=0,949 \text {. }
$$

Высокое значение коэффициента детерминации указывает на близость математической модели к эмпирическим наблюдениям; линейная взаимосвязь - на стандартизацию площадей участков в хозяйстве, после выдела которых остаются нестандартные участки.

Анализ данных статистики показывает, что на максимальном расстоянии от населенного пункта и административного центра находятся более крупные земельные участки $(\mathrm{r}=0,797$ и 0,741150 соответственно), на минимальном - более мелкие $(\mathrm{r}=0,521)$. Максимальная удаленность земельного участка от усадьбы влияет на его площадь согласно уравнению (2)

$$
\mathrm{y}=0,003 \mathrm{x}+16,26, \text { при } \mathrm{R}^{2}=0,572 \text {. }
$$

Минимальное расстояние до административного центра на площадь участков не влияет. Максимальное и минимальное расстояние до границы участка коррелируют с высокой степенью $(0,894)$. При близких в среднем площадях участков «шаг» между ними у разных участков близок по величине.

Тенденция зависимости между площадью земельного участка и его удаленностью от усадьбы описывается уравнением (3):

$$
\mathrm{y}=0,001 \mathrm{x}+11,48 \text {, при } \mathrm{R}^{2}=0,234 \text {. }
$$

Низкое значение коэффициента детерминации свидетельствует о слабой связи анализируемых процессов.

Таким образом, показано, что в Томском районе природные факторы не оказывают достоверно значимого влияния на размеры земельных участков с.-х. назначения, хотя при выделении долей бонитет почв был учтен. Несмотря на стихийный характер перераспределения земельных участков в ходе проведения аграрной реформы, в целом сохраняется оптимальный размер подавляющего большинства земельных участков в Томском районе. Это позволяет обеспечивать территориальную равномерность выхода с.-х. продукции отдельных культур, планирование близких объемов полевых работ по годам смены севооборота, контроль и учет хода их выполнения. Обращает на себя внимание недооценка плодородия и ландшафтных особенностей почв в вопросах планирования размеров поля.
Возможность уменьшения размеров земельных участков на более плодородных почвах и увеличение на менее плодородных в Томском районе не практикуется.

\section{Выводы}

1. Выборка из значений 3309 земельных участков и 25 хозяйств Томского района имеет ненормальное бимодальное распределение случайной величины.

2. Использование иерархического кластерного анализа позволило создать классификацию размеров площадей земельных участков с.-х. назначения с таксонами: «Общие размеры участка», «Масштаб», «Стандартизация по близости к региональному стандарту», «Относительные отклонения от стандарта», «Относительные размеры» и «Принадлежность к хозяйству». Классификация позволяет идентифицировать группы участков с наименьшими различиями в размерах площади.

3. Выявлена сложившаяся структура распределения земельных участков по площади: «Малые» (0-10 га), «Средние» (10-30 га), «Крупные» (30-38,5 га). В каждой части выделяются интервалы с очень высоким относительным накоплением частот: малые - 4-6 га, средние 19-22 га, крупные (бимодальны с интервалом 30-31 и 32-33 га).

4. В Томском районе такие природные факторы, как тип почв, бонитет почв, положение в ландшафте, хозяйственное назначение и использование, не оказывают влияние на площадь с.-х. участка.

5. Между средней площадью земельного участка и числом участков в хозяйстве существует линейная взаимосвязь.

6. Диапазон изменчивости площадей хозяйств составляет $240,4-9885,5$ га. На одно хозяйство в среднем приходится 157,24 участка; максимум - 502, минимум - 19 (в 26 раз меньше). На 1 га земель приходится 0,053 ед./га; максимум - 0,198 ед./га, минимум - 0,012 ед./га (в 16 раз меньше). Средняя площадь земельного участка в Томском районе равна 20,4 га. Преобладают участки площадью 15-20 га (43\%), около $30 \%$ имеет площадь в 20-25 га, около $14 \%$ - 10-15 га. Около $60 \%$ земельных участков имеют площади от 19,90-24,90 га.

7. Площади непригодные и мало пригодные (закустаренные) для ведения сельского хозяйства составляют $44 \%$. Кормовыми культурами занята почти половина земель, садовыми и овощными -7 и $2 \%$ соответственно. Доминируют серые лесные почвы (45\% участков), 14 \% участков покрыты светло-серыми лесными глееватыми почвами, по 11 \% - аллювиальные дерновые, темно-серые лесные, дерновые глубоко- и неглубокоподзолистые, дерновые мелкоподзолистые. Дерновые глубоко-подзолистые, дерново-глеевые и дерново-глееватые 
почвы практически отсутствуют. Положение земельных участков с.-х. назначения в ландшафте в основном элювиальное $(72 \%$ участков) и трансэлювиальное (21\% участков). Mенее сотни участков находятся в супераквальном положении. Участки в субаквальных типах элементарного ландшафта практически не встречаются.

8. Расстояния от административного центра до границы земельного участка изменяются в пределах: минимальное 0,1-12,2 км; максимальное $3,6-24,8$ км. Расстояние от г. Томска изме-

\section{СПИСОК ЛИТЕРАТУРЫ}

1. Pomelov A.S., Pasko 0.A., Baranova A.V. Comparative analysis of land management in the world // IOP Conference Series: Earth and Environmental Science. - 2015. - V. 27: Problems of Geology and Subsurface Development. - 4 p. URL: https://www.researchgate.net/publication/283847949_Comparative_analysis of land management in the world (дата обращения 10.12.2018).

2. Александрова Э.А., Гергаулова Р.М., Шрамко Г.А., Князева Т.В. Способ обработки озимой пшеницы: пат. № 2349071 РФ; опубл. 20.03.2009. Бюл. № 8.

3. Комов Н.В., Чешев А.С. Комплексный подход к планированию и рациональному использованию земельных ресурсов // Экономика и экология территориальных образований. - 2018. T. 2. - № 1. - C. 6-21.

4. European Commission. Structure and Dynamics of EU Farms: Changes, Trends and Policy Relevance // EU Agricultural Economics Briefs. - Brussels, 2013. - № 9. - 120 p.

5. Sikk K., Maasikamäe S. Impact of agricultural and holding size on the land fragmentation // Research for rural development. 2015. - V. 2. - P. 301-305.

6. Бочаров М. 0 минимальных размерах земель с.-х. назначения // Земельный вопрос. - 2005. - № 6 (45). - С. 77-82.

7. Land resource planning for sustainable land management food and agriculture organization of the united nations Rome / F. Nachtergaele, P. Groppo, R. Biancalani, S. Zelaya, S.Z. Bonilla, T. Fetsi, R. Rosalud, T. Hammond, S. Schlingloff. - Rome: Food and agriculture organization of the United nations, 2017. $68 \mathrm{p}$.

8. The issues of weed infestation with environmentally hazardous plants and methods of their control / V.L. Bogdanov, T.S. Posternak, O.A. Pasko, V.F. Kovyazin // IOP Conference series. Earth and Environmental Science. - Tomsk, 11 October 2016. - V. 43. Iss. 1. - P. 2-7.

9. Pokk M., Maasikamäe S., Sikk K. Aspects of arable land plots fragmentation in Tartu county Rural Development and Challenges Establishing Sustainable Land Use in Eastern European Countries // Land Use Policy. - 2012. - V. 30. - P. 703-710.

10. Bigelow D., Borchers A., Hubbs T. US Farmland Ownership, Tenure, and Transfer 2016. URL: https://www.ers.usda.gov/webdocs/publications/74672/60297_eib161_summary.pdf?v=0 (дата обращения 10.12.2018).

11. Horjan 0. Iuridiceskie problem consolidatii zemeli v Respublike Moldova // Proc. of International Scientific Methodical Conference Baltic Surveying 2010. - Vilnius: Lithuanian University of Agriculture, 2010. - P. 145-150.

12. Szabo L'., Grznár M. Agriculture in the EU and position of the Slovak Republic // Agricultural Economics. - 2015. - V. 61. P. $493-501$.

13. Павлова Т.И. Оптимизация почвенного плодородия в агроэкосистемах.- Саратов: ФГБОУ ВПО «СГАУ», 2014. - 35 с.

14. 0 земельных отношениях в Томской области (с изменениями на 10 сентября 2018 года) Закон Томской области от 9 июля няется в пределах: минимальное 3,2-33,2 км; максимальное 6,1-53,7 км. Выявлена достоверная корреляционная зависимость средней силы: положительная между площадью земельного участка и ее периметром и отрицательная между площадью земельного участка и коэффициентом компактности. Площадь хозяйства практически прямо пропорциональная числу участков, входящих в ее состав.

Работа выполнена в Толском политехническом университете в рамках програмлы повышения конкурентоспособности Толского политехнического университета.

2015 года № 100-03. URL: http://docs.cntd.ru/document/ 467921799 (дата обращения 10.12.2018).

15. Оценка почв / В.И. Савич, Х.А. Амергужин, И.И. Карманов, Д.С. Булгаков, Ю.В. Федорин, Л.А. Карманова. - Астана: Изд-во Каз. агротехн. ун-та, 2003. - 544 с.

16. 0 среднерайонной норме бесплатной передачи земли в собственность граждан. URL: http://docs.cntd.ru/document/ 9017422 (дата обращения 10.12.2018).

17. Каличкин В.К. Ресурсный потенциал сельского хозяйства Томской области / Сб. мат. и докладов Первого Агрономического собрания Томской области. - Томск, 2016.- С. 12-26.

18. Дюкарев А.Г. 0 зонировании Томской области по агроклиматическим условиям и почвенному плодородию / Сб. мат. и докладов Первого Агрономического собрания Томской области. Томск, 2016. - C. 87-92.

19. Тюменцев Н.Ф., Иоганзен Б.Г. Природные биологические ресурсы Томской области и перспективы их использования. Томск: Изд-во Томского университета, 1966.- 126 с.

20. Томский округ. URL: http://www.mediatly.com/Cards/view/115019 (дата обращения 10.12.2018).

21. Карта районов Томской области. URL: https://www.google.ru/maps (дата обращения 10.12.2018).

22. Портал Росреестра. URL: //rosreestr.ru/site/ (дата обращения 10.12.2018).

23. Публичная кадастровая карта Томской области. URL: https://egrp365.ru (дата обращения 10.12.2018).

24. Google Earth. URL: https://www.google.ru/intl/ru/earth/ (дата обращения 10.12.2018).

25. «Постановление главы Администрации Томской области 0 нормативной цене земли на 2004 год от 14.04.2004 г. № 60». URL: http://docs.cntd.ru/document/951808515 (дата обращения 10.12.2018).

26. Стандарт межгосударственный. ГОСТ 17.8.1.02-88 (СТ СЭВ 6005-87). Охрана природы. Ландшафты. Классификация: утв. Постановлением Государственного комитета СССР от 13.05.1988 г. № 1329. - М.: ИПК Изд-во стандартов, 1988. - 6 с.

27. Глазовская М.А. Геохимические основы типологии и классификации природных ландшафтов.- Смоленск: Ойкумена, 2002.- $288 \mathrm{c}$.

28. Волков С.Н. Землеустройство. Т. З. Землеустроительное проектирование. Межхозяйственное (территориальное) землеустройство. - М.: Колос, 2002. - 384 с.

29. Reiff M., Ivanicova Z., Surmanova K. Cluster analysis of selected world development indicators in the fields of agriculture and the food industry in European Union countries // Agricultural Economics. - 2018. - № 5. - P. 197-205.

30. Захарченко А.В., Алексеев В.И., Ипатова Д.В. Иерархическая концепция неоднородности почв и планирование масштабов исследований // Иввестия Томского политехнического университета. Инжиниринг георесурсов. - 2016. -Т. 327. -№ 4. - С. 149-163.

Поступила 08.02.2019 2. 


\section{Информация об авторах}

Пасько О.А., доктор сельскохозяйственных наук, профессор отделения геологии Инженерной школы природных ресурсов Национального исследовательского Томского политехнического университета.

Захарченко A.B., доктор биологических наук, главный научный сотрудник Института проблем освоения Севера Федерального государственного бюджетного учреждения науки Тюменского научного центра Сибирского отделения Российской академии наук.

Поспелова E.B., аспирант Национального исследовательского Томского политехнического университета. 


\title{
AREA DIFFERENTIATION OF AGRICULTURAL LAND ON THE EXAMPLE OF TOMSK DISTRICT
}

\author{
Olga A. Pasko', \\ oap@tpu.ru
}

\author{
Alexandr V. Zakharchenko², \\ zakh.al.vic@yandex.ru \\ Ekaterina V. Pospelova', \\ kate_frol@mail.ru \\ ${ }^{1}$ National Research Tomsk Polytechnic University, \\ 30, Lenin Avenue, Tomsk, 634050, Russia. \\ 2 Institute of the problems of Northern development of Siberian Branch of the Russian Academy of Sciences, \\ 86, Malygin Avenue, Tyumen, 625026, Russia.
}

The relevance of the research is caused by the need to optimize the size of land plots to improve the organization of using agricultural land in the area of risky farming.

The aim of the study is to analyze the existing spatial distribution of land plots for agricultural purposes to choose the ways to optimize their use.

The objects of the research are the 3309 agricultural land plots of 25 farms located in the South-East of Tomsk region.

Methods: analytical, cartographic, correlation, regression and cluster types of analysis.

Results. The authors have analyzed the sample of 3309 land plots from 25 farms of the Tomsk district, and determined its main statistical indicators. Polymodality of the sample and its nonconformity to the normal distribution were established by nonparametric methods of analysis. Based on the hierarchical cluster analysis, the authors proposed the taxonomy (total plot size, scale, standardization by proximity to the regional standard, relative deviations from the standard, relative sizes and affiliation to the farm) and classification of areas for agricultural land plots. Agriculture accounts for $44 \%$ of the total. Almost half of the land is used for fodder crops, and 7 and $2 \%$, respectively, for garden and vegetable crops. Gray forest soils dominate (45\% of plots), $14 \%$ of plots are covered with light gray forest soils, and $11 \%$ are covered with all other types. Sod deep-podzolic, sod-gley and sod-gley soils are rarely found on agricultural lands. The position of land in the landscape is mainly eluvial ( $72 \%$ of the plots) and transeluvial ( $21 \%$ of the plots). Less than a hundred of plots are characterized by superaqual soils. It is shown that in the Tomsk district such factors as soil type, soil bonitet, position in the landscape and economic purpose do not affect the area of the agricultural plot. A linear relationship was established between the average land area and the number of land plots in the farm, which indicates the standardization of the land plots, after selection.

\section{Key words:}

Land, agricultural purpose, area, type of soil, credit score, position in the landscape, cluster analysis, correlation analysis, classification, land use deficiencies.

The work was carried out at the Tomsk Polytechnic University as a part of the program to improve the competitiveness of the Tomsk Polytechnic University.

\section{REFERENCES}

1. Pomelov A.S., Pasko 0.A., Baranova A.V. Comparative analysis of land management in the world. IOP Conference Series: Earth and Environmental Science, 2015, vol. 27, 4 p. Availablehttps://www.researchgate.net/publication/283847949_Comparative_analysis_of_land_management_in_the_world (accessed 10 December 2018).

2. Aleksandrova E.A., Gergaulova R.M., Shramko G.M., Knyazeva T.V. Sposob obrabotki ozimoy pshenitsy [Method of processing winter wheat]. Patent RF, no. 2349071, 2009.

3. Komov N.V., Cheshev A.S. An integrated approach to planning and rational use of land resources. Ekonomika i ekologiya territorialnykh obrazovaniy, 2018, vol. 2, no. 1, pp. 6-21. In Rus.

4. European Commission: Structure and Dynamics of EU Farms: Changes, Trends and Policy Relevance. EU Agricultural Economics Briefs. Brussels, 2013. No. 9, 120 p.

5. Sikk K., Maasikamäe S. Impact of agriculturall and holding size on the land fragmentation. Research for rural development, 2015, vol. 2, pp. 301-305.

6. Bocharov M. On the minimum size of agricultural land. In terra proventus, 2005, no. 6 (45), pp. 77-82. In Rus.
7. Nachtergaele F., Groppo P., Biancalani R., Zelaya S. Bonilla S.Z., Fetsi T., Rosalud R., Hammond T., Schlingloff S., Mantel S. Land resource planning for sustainable land management food and agriculture organization of the united nations Rome. Rome, Food and agriculture organization of the United nations, 2017. $68 \mathrm{p}$.

8. Bogdanov V.L., Posternak T.S., Pasko 0.A., Kovyazin V.F. The issues of weed infestation with environmentally hazardous plants and methods of their control. IOP Conference series. Earth and Environmental Science. Tomsk, 11 October 2016, vol. 43, no. 1, pp. 2-7.

9. Pokk M., Maasikamäe S., Sikk K., Pašakarnis G. Aspects of arable land plots fragmentation in Tartu county. Rural Development and Challenges Establishing Sustainable Land Use in Eastern European Countries. Land Use Policy, 2012, pp. 703-710.

10. Bigelow D., Borchers A., Hubbs T. US Farmland Ownership, Tenure, and Transfer 2016. Available at: https://www.ers.usda.gov/webdocs/publications/74672/60297_eib161_summary.pdf? $\mathrm{v}=0$ (accessed 10 December 2018).

11. Horjan 0. Iuridiceskie problem consolidatii zemeli v Respublike Moldova [Legal problems of land consolidation in the Republic of 
Moldova]. Proceedings of International Scientific Methodical Conference Baltic Surveying. Lithuanian University of Agriculture. Vilnius, 2010. pp. 145-150.

12. Szabo L'., Grznár M. Agriculture in the EU and position of the Slovak Republic. Agricultural Economics, 2015, no. 61, pp. 493-501.

13. Pavlova T.I. Optimizatsiya pochvennogo plodorodiya v agroekosistemakh [0ptimization of soil fertility in agro-ecosystems]. Saratov, FGBOU VPO «SGAU» Publ., 2014. 35 p.

14. 0 zemelnykh otnosheniyakh $v$ Tomskoy oblasti (s izmeneniyami na 10 sentyabrya 2018 goda) Zakon Tomskoy oblasti ot 9 iyulya 2015 g. no. 100, Zakonodatelnaya duma Tomskoy oblasti [On Land Relations in the Tomsk Region (as amended on September 10, 2018) Law of the Tomsk Region dated July 9, 2015 No. 100]. Available at: http://docs.cntd.ru/document/467921799 (accessed 10 December 2018).

15. Savich V.I., Amerguzhin Kh.A., Karmanov I.I., Bulgakov D.S., Fedorin Yu.V., Karmanova L.A. Otsenka pochv [Assessment of soils]. Astana, Kazakh Agrotechnical University Publ. house, 2003. $544 \mathrm{p}$

16. 0 srednerayonnoy norme besplatnoy peredachi zemli $v$ sobstvennost grazhdan [0n average norm of free transfer of land to the ownership of citizens]. Available at: http://docs.cntd.ru/document/9017422 (accessed 10 December 2018).

17. Kalichkin V.K. Resursny potentsial selskogo khozyaystva Tomskoy oblasti [Resource potential of agriculture in Tomsk region]. Sbornik materialov i dokladov pervogo agronomicheskogo sobraniya Tomskoy oblasti [Collection of materials and reports of the First Agronomic Assembly of the Tomsk Region]. Tomsk, 2016. pp. $12-26$.

18. Dyukarev A.G. 0 zonirovanii Tomskoy oblasti po agroklimaticheskim usloviyam i pochvennomu plodorodiyu [On the zoning of the Tomsk region on agro-climatic conditions and soil fertility]. Sbornik materialov i dokladov pervogo agronomicheskogo sobraniya Tomskoy oblasti [Materials and reports of the First Agronomic Assembly of the Tomsk Region]. Tomsk, 2016. pp. 87-92.

19. Tyumentsev N.F., Ioganzen B.G. Prirodnye biologicheskie resursy tomskoy oblasti i perspektivy ikh ispolzovaniya [Natural biological resources of the Tomsk region and the prospects for their use]. Tomsk, TGU Publ., 1966. $126 \mathrm{p}$.

20. Tomskiy okrug [Tomsk district]. Available at: http://www.mediatly.com/Cards/view/115019 (accessed 10 December 2018).
21. Karta rayonov Tomskoy oblasti [Map of districts of the Tomsk region]. Available at: https://www.google.ru/maps_(accessed 10 December 2018).

22. Portal Rosreyestra [Rosreestr portal]. Available at: rosreestr.ru/site/ (accessed 10 December 2018).

23. Publichnaya kadastrovaya karta Tomskoy oblasti [Public cadastral map of the Tomsk region]. Available at: https://egrp365.ru (accessed 10 December 2018).

24. Google Earth. Available at: https://www.google.ru/intl/ru/ earth/ (accessed 10 December 2018).

25. Postanovlenie glavy Administratsii Tomskoy oblasti o normativnoy tsene zemli na 2004 god ot 14.04.2004 g. № 60 [Resolution of the Head of the Tomsk Region Administration on the normative price of land for 2004 of April 14, 2004 No. 60]. Available at: http://docs.cntd.ru/document/951808515 (accessed 10 December 2018).

26. Standart mezhgosudarstvenny. GOST 17.8.1.02-88 (ST SEV 6005-87). Okhrana prirody. Landshafty. Klassifikatsiya: utv. Postanovleniyem Gosudarstvennogo komiteta SSSR ot $13.05 .1988 \mathrm{~g}$. № 1329 [Interstate standard. SS 17.8.1.02-88 (ST SEV 6005-87). Protection of Nature. Landscapes. Classification: approved. Resolution of the State Committee of the USSR of 13/05/1988 No. 1329]. Moscow, Izdatelstvo standartov, 1988. $6 \mathrm{p}$.

27. Glazovskaya M.A. Geokhimicheskiye osnovy tipologii i klassifikatsii prirodnykh landshaftov [Geochemical basis of typology and classification of natural landscapes]. Smolensk, Oikumena, 2002. $288 \mathrm{p}$.

28. Volkov S.N. Zemleustroystvo. T. 3. Zemleustroitelnoe proektirovanie. Mezhxozyaystvennoe (territorialnoe) zemleustroystvo [Land Management. Vol. 3. Land management design. Inter-farm (territorial) land management]. Moscow, Kolos Publ., 2002. 384 p.

29. Reiff M., Ivanicova Z., Surmanova K. Cluster analysis of selected world development indicators in the fields of agriculture and the food industry in European Union countries. Agricultural Economics, 2018, no. 5, pp. 197-205.

30. Zakharchenko A.V., Alekeev V.I., Ipatova D.V. Hierarchical concept of soil heterogeneity and planning the scale of investigations. Bulletin of the Tomsk Polytechnic University. Geo Assets Engineering, 2016, vol. 327, no. 4, pp. 149-163. In Rus.

Received: 8 February 2018.

\section{Information about the authors}

Olga A. Pasko, Dr. Sc., professor, National Research Tomsk Polytechnic University.

Alexandr V. Zakharchenko, general research fellow, Institute of the problems of Northern development.

Ekaterina V. Pospelova, postgraduate student, National Research Tomsk Polytechnic University. 